\title{
Nordic Social Work Research
}

\section{Adjusting to standards: reflections from 'auditees' at residential homes for children in Sweden}

\section{David Pålsson}

To cite this article: David Pålsson (2016): Adjusting to standards: reflections from 'auditees' at residential homes for children in Sweden, Nordic Social Work Research, DOI: 10.1080/2156857X.2016.1192054

To link to this article: http://dx.doi.org/10.1080/2156857X.2016.1192054

曲 Published online: 30 May 2016.

Submit your article to this journal $₫$

Џ Article views: 23

Q View related articles $\sqsubset$

View Crossmark data 


\title{
Adjusting to standards: reflections from 'auditees' at residential homes for children in Sweden
}

\author{
David Pålsson \\ Department of Social Work, Stockholm University, Stockholm, Sweden
}

\begin{abstract}
In recent years, state inspection of Swedish residential care for children has been reinforced. This study explores how inspections are perceived from the point of view of residential staff. The empirical material is based on interviews $(n=23)$ with residential staff and managers $(n=55)$ of residential homes subject to requirements from the Swedish Inspectorate. The material has been analysed using concepts shedding light on the different aspects of how audit affects'auditees'. The results suggest that inspections have mainly shaped the administrative part of care; that compliance with regulatory standards bring about stability in the work performed; that the standard-setting sometimes creates tensions between professional judgment and formal authority; and that inspections play an accreditation role for the residential homes. The implications of this are discussed, e.g. that the regulatory standards seem to target aspects of care that are alternatives to those of evidence-based practice, that general standards to some extent challenge the possibilities of organising the care according to the individual needs of the children and that the receptiveness of professionals to inspection ideas entails both possibilities and obstacles for the development of a professional field.
\end{abstract}

\section{KEYWORDS}

Residential care for children; inspection; audit; out-ofhome care

\section{Introduction}

How do staff at institutions that provide care for children reason about inspections? In recent years, Swedish state inspection covering residential care has undergone several reforms. A new, more centralised Inspectorate, the IVO (The Inspectorate of Health Care and Social Welfare), has been established and each residential home is inspected on-the-spot twice a year. The increased importance assigned to inspections is not unique to Sweden, rather it is part of an international trend in which more and more resources are invested in monitoring the outcomes of welfare services (Hood et al. 1999; Power 1999; Johansson and Lindgren 2013). In the case of Swedish residential care in particular, the driving forces have been a rapid privatisation of the services (Meagher et al. 2015) paired with concerns about the quality of care (NAO (National Audit Office) 2002). This culminated in the 'Inquiry into Abuse and Neglect' that revealed a series of cases of maltreatment in the past (SOU 2009:99). Inspections are indeed one of the most powerful ways through which a state can control goods and services (Bemelmans-Videc, Rist, and Vedung 2010) and the underlying assumption is that given that different regulatory standards are met to a higher degree, the quality of the care will consequently increase (Boyne, Day, and Walker 2002). However, knowledge about how residential managers and staff (the 
'auditees'), i.e. those whose work the monitoring is geared at, are affected by inspections is lacking in Sweden and to a large extent also internationally.

This study forms part of a larger research project which aims to study the control system of outof-home care in Sweden (e.g. Pålsson 2015; Meagher et al. 2015; Sallnäs \& Wiklund 2015a; Sallnäs \& Wiklund 2015b). In the article, I explore how inspections are perceived from the point of view of representatives of residential homes. The empirical material is based on interviews with managers and staff affiliated to residential homes for children. To analytically approach the material, certain main concepts have been used to shed light on how 'auditees' are affected by inspections (Power 1999, 2003, 2010), e.g. that audits underpin standard-setting in favour of professional discretion; have formative effects and thus are constitutive of the organisation of the residential homes; and that living up to standards has implications on organisational legitimacy. In line with these considerations, the following research questions are posed: How do residential managers and staff reason about the standard-setting in relation to their work? To what extent, if any, do inspections and inspection standards shape their work? What importance do they attribute to inspections and inspection reports?

\section{Rising placements, privatisation and de-professionalisation}

In Sweden, as in many other countries, residential care has been singled out as a 'last resort' among child welfare interventions. In the last few decades, however, placements have increased steadily and on a given date in 2013 residential care affected around 8000 children, more than a third of all placements in out-of-home-care (NBHW 2014). Residential care is a heterogeneous field in terms of the type of care (secure units, treatment institutions and supported accommodation) as well as target groups (children with behavioural problems, unaccompanied refugee minors, and children and their families) (Sallnäs 2012). Influenced by the New Public Management reforms that were launched in the 1980s, there has been a steady growth of private providers (currently $50-70 \%$ of all institutions) (Meagher et al. 2015). From being a field that comprised many small-scale businesses, larger firms have increased their market shares. The establishment of a 'quasi-market' (Le Grand and Bartlett 1993) has increased the need for regulations to prevent market imperfections and made transparency more urgent for the social services when procuring and assessing the care provided.

Like its international equivalents, Swedish residential care has been depicted as a 'de-professionalised' field with little overall consensus on the core values of the work (Sallnäs 2012; Whittaker et al. 2014). There are various types of professions operating in the field, nearly half of the employees have no formal education and the methods practiced differ considerably (IVO 2013). Swedish residential care is not evaluated to any large extent, but studies have revealed a high prevalence of disruptions (Sallnäs, Vinnerljung, and Kyhle Westermark 2004), unsatisfactory access to welfare resources (Sallnäs, Wiklund, and Lagerlöf 2012) and poor long-term effects (Sallnäs and Vinnerljung 2008). The Swedish government advocates the application of evidence-based interventions (Bergmark, Bergmark, and Lundström 2011), but the use of specific methods remains unregulated and hence, is not formally monitored by the Inspectorate. Further, there is an established research discourse that downplays the importance of specific treatment elements (Barth et al. 2014). Here, potentially positive effects are mainly attributable to therapeutic alliances between child and treatment staff and common elements. Internationally, there is growing evidence that strong school support, viable relationships between children and adults, collaboration with the birth family and powerful leaving care are important prerequisites for achieving positive results (Whittaker et al. 2014).

\section{A growing control apparatus}

Since 2010, the inspection system of residential care has been reformed (SOU 2007:82). For example, the Inspectorate visits each residential home twice a year where at least one visit should be unannounced and a national telephone number intended for children in out-of-home care has been established. The 
regulations surrounding residential care set the framework for the areas to be inspected and these encompass, for example, quality management systems, personnel and staffing, security, collaboration, documentation and the needs of the child, which in turn are operationalized into measurable standards by the Inspectorate (NBHW [The National Board of Health and Welfare] 2010). The specific standards that are inspected amend annually and it is the Inspectorate to decide which standards are to be monitored. In order to investigate compliance inspectors usually conduct interviews with managers, staff and children, and review documents. Each inspection visit results in an inspection report that becomes public on a national web-based register. Regarding inspection systems, a distinction is often made between controlling (i.e. the tendency towards clear-cut measures and sanctions) and promoting types (i.e. the tendency towards less clear-cut measures and more advice) and it is still unclear which route the Swedish inspections of social services has taken (Hämberg 2014).

The audits may to greater or lesser extent concern 'second-order functions', i.e. that control systems intended to guide the work are at place, or first-order activities, i.e. the actual performance of the auditees (Power 1999, 2003). Not least the presence of a quality management system is increasingly equated with good quality in public services (Dahler-Larsen 2008). The standards may certainly target important areas of care, but may also increase administration which is only relevant for the client work to a varying extent (Tilbury 2007; see also Watson 2003) and may lead to 'goal displacement' if the standards monitored focus too much on certain areas while deprioritizing others (Munro 2004; de Wolf and Janssens 2007). For the professionals, increased standard setting may entail mixed implications. A study on the Norwegian audit apparatus of residential care revealed, on the one hand, that greater emphasis had been placed on formal education and hence professional knowledge was valued (Nordstoga and Stokken 2011). On the other hand, more detailed demands have been imposed on, for example, documentation and the use of certain approved methods, and hence professional discretion has been curbed.

\section{Standard-setting, formative effects and legitimacy}

To analytically approach the influence inspections have over residential homes, I use concepts derived from the works of Power $(1999,2003,2010)$ that elucidate different aspects of how audits work in relation to the 'auditees'. In this study, the concepts serve to sort the empirical material as well as to draw analytical attention to the critical aspects of audits of residential care for children that have been formulated in previous research covering other fields.

First, as audit underpins compliance with standards rather than reliance on professional discretion (Power 1999; Svensson 2010; Evetts 2011), the analysis is aimed at how standard setting influences residential practices. Increased focus on standard setting is sometimes presumed to curtail the space for professional judgment in a way that may not always be preferable (Shore and Wright 2000), but undoubtedly it may also contribute to discarding undesirable practices and enhancing the minimum level of care. Second, inspections have formative effects, which means that standards define socially what is regarded as important in the provision of care and thereby encourage the residential homes to organise their work so that the standards are met (Power 1999, 2003). For example, the auditees are driven to ensure that their work is transparent for outsiders and to continuously ensure that there is an audit trail like for instance documentation showing that they comply with the standards. Third, regardless of whether the standards per se make substantial or minor imprints on the practices, inspections have a symbolic value in that they may strengthen or weaken the organisational legitimacy (Meyer and Rowan 1977; Power 1999, 2010). Positive inspection reports might - at least theoretically - serve to consolidate the position of a residential home in the care market, whilst negative reports may sully the trademark of a residential home. The incentive to comply with the standards is thus likely to be increased for reputational reasons, since passing inspections and adhering to officially sanctioned practices is connoted with 'good quality'. 


\section{Material and methods}

The study draws on qualitative interviews (Silverman 2013) including 55 representatives of residential homes, of whom 13 where managers and 42 residential staff.

The study was approved by a regional ethical review board. As the aim of the article was to understand how inspections work in relation to residential care, I selected residential homes that had experienced clear interaction with the Inspectorate. The definition for this was that the residential home had recently been subject to requirements, i.e. had failed to live up to a specific standard and thus, had been required to make organisational changes in order to achieve compliance. To gain access to such residential homes, I contacted each of the six Inspectorate offices and asked them to provide information on residential homes that in 2013 received requirements. This resulted in a list of 153 residential homes with different types of requirements. Using SPSS, I randomly selected 3 homes per region, which generated a sample 18 residential homes. The reason behind the regional spread was that inspections are executed on a regional basis and thus, theoretically, may vary, and so by randomly selecting different institutions it was possible to study a variety of the phenomena. Of the 18 homes, one home had closed down, one home chose not to participate and I failed to gain contact with three of the homes. The final sample consisted of 13 residential homes, which differed regarding, for example, ownership, size and target group. The standards that the residential homes did not live up to in 2013 involved, for example, the quality management system, Lex Sarah ${ }^{1}$, system of complaints, involvement of the children etc. In Table 1, there is a presentation of the residential homes included in the study.

The residential homes were visited on-the-spot during the period September-December 2014 at times when the manager informed that staff would be present. The interview data consisted of individual interviews with managers or persons in equivalent positions (e.g. assistant manager) $(n=11)$, interviews with the manager and staff in tandem $(n=2)$ and group interviews with residential staff $(n=10)$. The reason for interviewing managers and staff separately, was that they were presumed to exhibit diverse experiences of inspections. For example, the managers are formally accountable for the performance of the residential home, while staff are likely to have knowledge about the implication of standards on residential practices. In the two cases, where I deviated from the principle of interviewing managers and staff separately, it was because the staff present asked to be interviewed together with the manager. The number of participants in the group interviews ranged from 2 to 9 . Thus, the study was based on a total of 23 interviews including 55 respondents. Regarding the interviewees, the managers had experienced several inspections and some had worked in residential care for a couple of decades. The staff had various experiences of inspections; most of them had experienced one or several inspections, while three of them had not been present during inspections at all. However, a direct experience was not decisive for participation in the study, since the interviews were to a large extent about how standards affect everyday work.

The interviews were semi-structured (Silverman 2013) and lasted between $45 \mathrm{~min}$ and $2 \mathrm{~h}$. The interviews with both managers and staff roughly followed the same interview protocol which covered themes like their experiences and strategies in relation to standards and what inspections mean to them. The interviews with the managers touched upon organisational aspects of care, while the interviews with staff frequently concerned client work. The accounts of staff and managers covered previous and current experience of inspections. Although the interviews touched upon the same themes, I was receptive to the respondents' accounts and the interviews took different turns. Regarding the group interviews, I endeavoured to let all voices be heard, by regularly inviting more passive participants into the discussions. To ensure validity in the interviewees' responses, I often repeatedly asked the same questions using different words.

The interviews were transcribed verbatim. My interest was in the contents and not in particular how views were expressed, and thus fillers were regularly excluded. The transcriptions were transferred into NVivo (qualitative data analysis computer software) to facilitate the coding of the material. Some of the interviews included sections on, for example, what the respondents' felt about meeting inspectors or their thoughts on the interviews with the children conducted by inspectors. These parts were not incorporated into the results, since they did not fall within the scope of the study. The transcriptions were reread several times and during the analysis I applied an abductive strategy insofar as the patterns 
Table 1. Residential homes included in the sample with details on region, type of care, provider, target group, standards of noncompliance and interviews.

\begin{tabular}{|c|c|c|c|c|c|c|}
\hline $\begin{array}{l}\text { Residential } \\
\text { home }\end{array}$ & Region & Type of care & Provider & Target Group & $\begin{array}{l}\text { Standards of noncom- } \\
\text { pliance in } 2013\end{array}$ & Interviews \\
\hline 1 & Middle & $\mathrm{Tl}^{\mathrm{a}}$ & Private & SPC & $\begin{array}{l}\text { - QMS } \\
\text { - Lex Sarah }\end{array}$ & $\begin{array}{l}\text { Manager }(n=1) \\
\text { Staff }(n=3)\end{array}$ \\
\hline 2 & Middle & $\mathrm{Tl}^{\mathrm{a}}$ & Private & $\mathrm{FC}^{\mathrm{d}}$ & $\begin{array}{l}\text { - QMS } \\
\text { - System for complaints }\end{array}$ & $\begin{array}{l}\text { Manager }(n=1) \\
\text { Staff }(n=1) \\
\quad \text { (together) }\end{array}$ \\
\hline 3 & Middle & $\mathrm{Tl}^{\mathrm{a}}$ & Private & URM $^{\mathrm{e}}$ & $\begin{array}{l}\text { - QMS } \\
\text { - Lex Sarah } \\
\text { - System for complaints }\end{array}$ & Manager $(n=1)$ \\
\hline 4 & Southwest & $S A^{b}$ & Public & URM $^{\mathrm{e}}$ & $\begin{array}{l}\text { - Children's involvement } \\
\text { - System for complaints }\end{array}$ & $\begin{array}{l}\text { Manager }(n=1) \\
\text { Staff }(n=6)\end{array}$ \\
\hline 5 & Southwest & $\mathrm{Tl}^{\mathrm{a}}$ & Private & $\mathrm{SPc}$ & $\begin{array}{l}\text { - Routines for monitor- } \\
\text { ing living quarters }\end{array}$ & $\begin{array}{l}\text { Manager }(n=1) \\
\text { Staff }(n=8)\end{array}$ \\
\hline 6 & Southwest & $S A^{b}$ & Private & URM $^{\mathrm{e}}$ & - System for complaints & $\begin{array}{l}\text { Manager }(n=1) \\
\text { Staff }(n=1) \\
\quad \text { (together) }\end{array}$ \\
\hline 7 & South & $S A^{b}$ & Private & $\mathrm{SPC}$ & - Lex Sarah & $\begin{array}{l}\text { Manager }(n=1) \\
\text { Staff }(n=6)\end{array}$ \\
\hline 8 & South & $S A^{b}$ & Private & URM $^{\mathrm{e}}$ & - System for complaints & $\begin{array}{l}\text { Manager }(n=1) \\
\text { Staff }(n=2)\end{array}$ \\
\hline 9 & Southeast & $S A^{b}$ & Public & URM $^{\mathrm{e}}$ & $\begin{array}{l}\text { - QMS } \\
\text { - Lex Sarah }\end{array}$ & $\begin{array}{l}\text { Manager }(n=1) \\
\text { Staff }(n=6)\end{array}$ \\
\hline 10 & North & $S A^{b}$ & Public & URM $^{\mathrm{e}}$ & - System for complaints & $\begin{array}{l}\text { Manager }(n=1) \\
\text { Staff }(n=2)\end{array}$ \\
\hline 11 & North & $S A^{b}$ & Public & URM $^{\mathrm{e}}$ & $\begin{array}{l}\text { - Routines regarding } \\
\text { security and risks } \\
\text { - System for complaints } \\
\text { - Lex Sarah }\end{array}$ & $\begin{array}{l}\text { Manager }(n=1) \\
\text { Staff }(n=3)\end{array}$ \\
\hline 12 & East & $\mathrm{Tl}^{\mathrm{a}}$ & Private & $\mathrm{FC}^{\mathrm{d}}$ & $\begin{array}{l}\text { - Age of child exceeds } \\
\text { that of permit } \\
\text { - System for complaints }\end{array}$ & $\begin{array}{l}\text { Manager }(n=1) \\
\text { Staff }(n=3)\end{array}$ \\
\hline 13 & East & $S A^{b}$ & Private & URM $^{\mathrm{e}}$ & $\begin{array}{l}\text { - Age of child exceeds } \\
\text { that of permit }\end{array}$ & $\begin{array}{l}\text { Manager }(n=1) \\
\text { Staff }(n=2)\end{array}$ \\
\hline
\end{tabular}

Treatment institution.

bSupported accomodation.

'Children with social problems.

dFamily care.

eUnaccompanied refugee minors.

fQuality management system.

identified in the empirical material were analysed in interaction with the theoretical concepts. Before finalising the overall analysis I reread the transcriptions in order to ensure that inconsistencies and deviant cases were presented. The analysis arrived at four themes, which were derived in an interplay between theoretical points of departure and empirical data.

Regarding limitations, the study concerns auditees which have been subject to requirements and thus they are not representative of auditees in general. Further, the aspects of care that are monitored change over time and hence the ways residential homes are shaped by inspections likewise change. It is also important to note that the study involves different types of residential homes, both those that provide treatment and those that do not provide treatment, and in the latter case the question of the effects of care is perhaps less urgent.

\section{Results}

In this section the empirical results are presented. The first theme (the administrative and managerial focus of inspection) shows how regulatory standards often target the management and accelerate the 
build-up of documented systems and routines designed to guide the care. The second theme (stability in a professional work in flux) shows that standards bring guidance to a context where there are few explicit professional guidelines and where there are important values at stake. The third theme (tensions between professional judgment and formal authority) outlines how the mandate for making decisions about the care is to some extent shifting from professionals to external regulators. The final theme (the accreditation role of inspections) shows how inspections are an important accreditation available for the residential homes to demonstrate that they provide decent care.

\section{The administrative and managerial focus of inspections}

According to several of the respondents' descriptions, inspections above all seem to have influenced the administration and the presence of routines in the residential homes. Several members of staff say that the fact that inspections take place encourages them to have formal aspects of the work in order, e.g. they explain that they more regularly go through the children's case files, skim through the journals and update different documentation and plans which may have been neglected. Several managers say that they, if they know in advance what areas will be monitored, set up meetings with the staff ahead of time to ensure that they are informed about the pending inspection and are able to account of their practices. This is discussed by several of the staff:

Member of staff 1: We get some information on what they will monitor and then we ensure that we improve on that.

Member of staff 3: Before, we never checked the children's involvement in the implementation plans. We just skipped that bit. And now, when we work with the plans, we immediately deal with the issue of involvement. So that has led to results. (Member of staff, residential home 7)

Several of the managers describe in particular inspections as helpful to them in their managerial roles and stress that it helps them to put pressure on social services so that they provide care plans more quickly and that inspections are a support for them in order to ensure that staff fulfil their tasks, for example, with regard to verifying that risk analyses are in place, that care plans have been drawn up and that journals are kept. The fact that the Inspectorate conducts visits forces staff to catch up and one manager says that then you almost get help from the IVO. Several of the managers also underscore that due to the regular inspections it is more important to document their actions concerning the areas that are inspected, something that is illustrated in one manager's quote:

We must be able to demonstrate that what we say is true. Like with the children's involvement that was recently monitored, then we talk about the house meetings we set up here with the children and how we can prove that we work in that way with them. //..// And then we had a whole lot of minutes from house meetings which we could show them. (Manager, residential home 5)

For many of the respondents, inspections have accelerated the process of transforming practices into explicit routines. Areas that are mentioned are, for example, more scheduled meetings with the children, a more organised way of noting complaints from clients, procedures regarding how to store medication, that the staff do rounds and ensuring that staffing levels entail that the residential home is never left unmanned etc. Some managers and staff claim that administrative routines and standards have had an impact on how they organise the care:

Member of staff 1: The routines change gradually. We review our routines.

Member of staff 2: For example, the matter of lex Sarah, there we took action immediately. We have introduced a system whereby we discuss all the incident reports, risk analyses, lex Sarah and so on at staff meetings every week. So this cannot be overlooked. (Member of staff, residential home 1)

Other members of staff say that inspections have had an impact on the administration, but not on how they relate to the children or apply their treatment, something which is underlined by one manager 'Of course the IVO affects us. //...// From the management system we're working with, to writing journal entries, care plans ... But in the practical work with the children I can't see that it affects what we do'. Some of them claim that since the active inspections have been ongoing for some years, they prepare less for the inspections. One manager - who heads a home affiliated to a larger corporation - explains 
that they have internal units that monitor the regulatory aspects of care, and this usually facilitates the inspection visits. One group of staff say that the inspections pass quite smoothly, since they are able to account for their procedures and explain how they work in different areas:

Member of staff 1: In the beginning them coming was a pretty big thing, and we cleaned everywhere (laughs). Now it feels like we remain more cool. I guess that has to do with the fact that we have improved over the years so that we now have a pretty good control

Member of staff 2: I agree, everyone is confident with the systems we have, everyone know that they work and exist. I don't think anybody feels put upon when the inspectors ask us questions. We have a pretty good track.

Researcher: What sort of systems are you referring to?

Member of staff 1: Like knowing the policy on Lex Sarah, the routines we have on checklists for accommodation, information. Anything. (Member of staff, residential home 12)

In sum, the results show that the formative effects of inspections have mainly led to a stronger focus on standards regarding the presence of routines intended to permeate the provision of care (cf. Power 1999, 2003). The standards that are highlighted primarily concern questions on different sorts of plans and procedures, measures taken to manage risks in the care and to enhance the involvement of the children in care. For the managers in particular, the standards often appear helpful. Since they have become increasingly used to inspections, several of the respondents say that inspections are more easily dealt with.

\section{Stability in a professional work in flux}

In many of the interviews the respondents, both staff and managers, say that inspections make them reflect on their work and prevent them from omitting important areas of care. Many of them say that inspections make them study their policies and formulate their practices within the specific areas that are monitored, something which is often viewed as beneficial. A large group of them stress that the fact that inspectors come on a regular basis prevents complacency:

You should see it as something positive, to learn what you can get better at. //...// Some stuff we miss here, and then someone from the outside sees that and then we fix it so that it's corrected. (Member of staff, residential home 7)

Several of the respondents also say that inspections help them understand what is demanded of them. A couple of the managers say that it is reassuring to obtain some sort of guidelines, since it makes them feel that there is a consensus on what is important in the provision of care. One manager says that the active inspection system relieves him of the feeling that he is alone in deciding how to organise the provision of care:

They facilitate my operations. Because they're constantly looking over my shoulder in decision-making. //...// And I think it's important for me to know that even if I make the decisions and am solely responsible for them, I still have a lot of people around me who are monitoring what I do. (Manager, residential home 7)

Some of the managers state that it is helpful to have guidelines since it helps them to anticipate criticism and ensure that their practices remain within the sanctioned limits. A couple of members of staff claim that even if in their opinion, a specific child may, for example, gain from being left alone for certain periods of time or it is not necessary to do rounds at night, it is reassuring to know that they have standards to abide by, not least if something in the care provided goes wrong. This is discussed by one manager who says that inspections are a form of security for me, I who am responsible for this and continues:

When you've received the report, you see that we do things the right way. Suddenly a situation may arise here, a fire or something like that, and then we may have some doubts. Have we done this correctly? Then you have a kind of guarantee that you work properly. (Manager, residential home 11)

A couple of the managers assert that they, when making decisions of various kinds, keep the Inspectorate in mind. For instance, the fact that they are periodically monitored has made them more cautious and resulted in them making a risk analysis more often before enrolling clients that may be too 
problem-burdened. Several of the managers say that it is less possible to get away with, for example, mixing groups. This is exemplified by one manager:

They sit on your shoulder. They sit there and affect you so that you become more rigorous. //...// If you take on someone and it turns out that he not only smoked cannabis once but that he was actually an addict. Then you have to do something about it, so it does not affect the other client. Because I know that if an inspection occurs, that's no good. (Manager, residential home 1)

Overall, the results show that inspections are often regarded as a way of obtaining information on what is demanded of them. Rather than resisting the orientation of the standards, they are considered important, providing guidelines and enabling them to anticipate criticism (cf. Power 2010). This often rather friction-free acceptance of external standards indicates that there often seems to exist a consensus between the Inspectorate and residential staff regarding what constitutes good residential care and reflect that residential care is a professional field which is receptive to external ideas regarding how to organise the provision of care.

\section{Tensions between professional judgment and formal authority}

Although the standards are often embraced, there are several examples of standards conflicting with the respondents opinions on what constitutes good care. The tensions particularly seem to arise in relation to standards relating to first order activities, such as housing solutions. One group of staff claim that their facilities do not live up to the standards, since all the children's rooms are not under one roof. However, they underscore that there are quarrels and that the children appear more contented living separately rather than together. Another group of staff said that the standard stipulating that children under a specific age are not allowed to live in a separate building, did not, in their case, benefit the child:

Member of staff 1: Before we had girls who were sixteen and seventeen years who lived in the apartment. And then they asked how old they were, and then we said that one is seventeen, one is eighteen and one is nineteen. And then they immediately replied 'oh, that's against the rules. Criticism.

Member of staff 2: So that could be the downside // // Because what we see as a flexible and good solution from our perspective, may from their perspective be illegal and then there is a clash. (Staff, residential home 5)

However, some of them say that it is sometimes possible to keep their solutions in place during a certain period of time by, for example, showing procedures for rounds, setting up alarms or conducting risk analyses, although some claim that such measures may feel contrived in cases where they trust the children. Further, a couple of managers and members of staff discuss the fact that a child's specific problems or age in some cases do not correspond with the institution's permit. This may occasionally lead to, for example, clients, who may have settled down, not being able to stay. One manager says that in situations when he believes that it is better for the child to stay, it is possible to take criticism from the Inspectorate:

Often it's about the permit, the rigidness of it. If you have someone who would fare well remaining in treatment for a few months, even if they're over 21 when our permit expires. In order to ensure an as smooth as possible move for that person //...// But then sometimes I choose to do what I believe is best and then take the criticism afterwards. (Manager, residential home 1)

Some of the staff and managers also say that the focus on 'second-order'-functions (cf. Power 2003) differs from what they regard as the professional core elements of the work. For example, some staff and managers explain that they have put a great deal of effort into developing quality management systems and written routines, but do not feel that they give them too much in return when it comes to the treatment of the children or the relationship building and that they just take up a lot of their time, time that could have been dedicated to client work instead. Some explain that they feel compelled to produce procedures and systems for events that seldom occur and say that they to a certain extent document for the sake of the Inspectorate, which is underlined by one manager:

It may be that we have to gather complaints. //...// But they (the residents, my note) say that it's unnecessary and that we solve it immediately. And then the IVO wants us to write down every complaint so that we can analyse them. And then it's like, all right, of course we should do that, but then we also have to devote a lot of time to it. (Manager, residential home 12) 
There are also examples indicating that there may be a certain tension between some standards emphasising the rights of the children and how the staff reason about treatment. For example, some of the respondents say that the focus on reducing the number of rules for the children has led to a situation where they feel unsure whether they may prevent a child from staying up all night or if they are not able to set rules for what they see as an excessive use of mobile phones. Some of them maintain that it may clash with what they themselves regard as important in the care:

Member of staff 1: Take mobile phones, may actually pose a greater risk for the child. They may expose themselves to more risks if they arrange meetings with dubious people //...// I think that you have to have been in such a situation in order to understand, and you shouldn't just say that they must be allowed to have their phones.

Member of staff 2: What would you do? Take her phone or let her have it and know that she'll meet a man outside? (Member of staff, residential home 1)

In sum, standard setting sometimes creates tension when it meets the understanding of the professionals concerning how the children's situation should be tackled. Standards are general and to underpin compliance with regulations results in professional judgment on how to organise the care being challenged by general solutions (cf Evetts 2011; Svensson 2010), although the results also show that there may be space for negotiations and thus that local solutions sometimes can be kept intact.

\section{The accreditation role of inspections}

The interviews also include many sections where the respondents explain that inspections make it possible for them to receive confirmation that they are performing satisfactorily. Both managers and staff often refer to inspection reports and the interviews with the children as a 'quality assurance' or 'proof' showing that they provide good care. One reason for this that emerges is that it provides them with a certain professional confidence:

We've received a lot of praise during the inspections. And then I communicate to the staff that the IVO thinks they're doing a brilliant job. It's great to be able to say that. So it might spur them on to continue doing a professional job. (Manager, residential home 13)

Further, especially among managers running private institutions, inspection reports are described as important for competitive reasons. For example, one home, which was affiliated to another home that was closed down by the Inspectorate, explains that in the aftermath of the closure they experienced suspicion and less of an influx of clients. Another couple of managers provide examples of when the media has picked up results from inspection reports and published them. Even though most of them do not sense that the inspection decisions play a significant role in their relationship with social services, they still say that they may be decisive for their possibilities to enrol clients:

Some of the social workers check what's written in the media. What does the Inspectorate say? Do we have to take measures? It's clear that an inspection report may be decisive for whether you get a placement or not //...// And therefore, I'm happy when they've been here and don't have any comments (Manager, residential home 7)

A couple of them underline that, apart from inspections, they have few other ways of evaluating their work. Inspection reports are considered to be authoritative and one manager running a private institution says that inspection reports constitute their yardstick showing that what we do is right and proper and continues:

And also from the outside, this is a private company, we make a living from municipalities around the country. We survive on our good reputation and on doing a good job. And these inspection reports can of course become a part of our marketing. (Manager, residential home 3)

However, also in the case of public sector residential homes, the interviews show that the inspection reports may be useful. One manager says that the inspection reports

can be proof that things have worked well //...// we can report to the political board that the Inspectorate has given us the go ahead, that they think that the home is well run. Then you get support from the politicians too. Several of the respondents, both managers and staff, also claim that the inspections may restore what they consider a bad reputation that corrodes the professional field. They say that inspections help to 
clear the field from entrepreneurs that provide poor care at the same time as they opens up for serious care givers to promote themselves. Inspections are thus a way of demonstrating that their performance has a high level of quality, which will hopefully reduce mistrust towards care providers in the field:

Member of staff 1: I just think it's positive. It helps to deny these rumours in society that there's so much misery. $/ / . . / /$ And I think it's uninformed and mean towards businesses that are serious providers of residential care.

When you at any time can go onto the IVO website and look up every home. (Member of staff, residential home 12)

Overall, inspections emerge as an opportunity to demonstrate that the homes work professionally. This is even more important given that there is a lack of other objective evaluations of their work. Although the actual importance of inspection reports appears unclear, they are regarded as an important form of accreditation proving that they provide decent care. Passing inspections is thus viewed as a way to reinforce the legitimacy of the residential home and in the long run raise the reputation of the entire field (cf. Meyer and Rowan 1977; Power 2010).

\section{Concluding discussion}

This article has explored the view of Swedish residential managers and the staff at residential homes, who are subject to requirements from the Inspectorate, on inspections in relation to their work. In recent years, a policy shift has resulted in state inspections having been assigned a salient role when it comes to securing quality in residential care. The study suggests that inspections make the auditees attentive to the areas audited and have mainly had an impact on the administrative parts of the provision of care; that compliance with regulatory standards bring about stability in the work performed; that tensions sometimes arise between the professional judgment of employees and what the standards stipulate; and that inspections play an accreditation role for the residential homes. The study has given rise to several points of discussion regarding the implication of inspections for residential care for children in Sweden.

First, the article shows that inspections have mainly led to a refining of systems and an increased attentiveness regarding standards relating to e.g. routines in the care provided, to the management of risks in care and to an increase in the involvement of the children. Notwithstanding that these may be pressing issues to be addressed, at the same time they only direct focus on certain aspects of the work (cf. Munro 2004; Tilbury 2007). In the light of the fact that the Swedish government advocates the need for evidence-based treatment interventions and how such are implemented (Bergmark, Bergmark, and Lundström 2011), the Inspectorate seems to have embarked on an alternative track. Bearing in mind that audits have a formative effect (Power 1999, 2003), this may induce a sort of 'goal displacement' where complying with regulatory standards is prioritised over determining which elements lead to the best possible effects of care (Munro 2004). However, it may admittedly also be complementary insofar as it places more weight on the documentation and follow up of the care and may facilitate local evaluations.

Second, in Swedish residential care, which is both a highly privatised and weakly professionalised welfare service (as regards educational attainments) (Sallnäs 2012), it becomes important to monitor compliance with rules in order to secure that there are some sort of minimum standards and to curb market imperfections. Put differently, it may be difficult to count on all residential homes providing care based on professional considerations and not for other reasons, such as the maximisation of profit or simply by practicing dubious methods. However, the downside with the increased focus on compliance with regulatory standards is - as argued in this article - that the space for professional judgment is sometimes restricted. The whole point of standards is that they are general and consequently not always ideal in serving the needs of an individual child (cf Evetts 2011; Svensson 2010). With the logic of public administration - according to which 'equality before the law' is the overarching hallmark this is perhaps secondary. However, from a professional point of view, standard setting may in some cases decrease the possibility of adjusting care to an individual child. 
Third, it is perhaps not particularly surprising that the managers and staff are often adaptive to the regulatory standards. Residential care is a professional field which lacks explicit consensus regarding the core values of the work, the standards capture areas of care that are important and difficult to object to, they often seem quite feasible to live up to and bring guidance and management to a complex line of work. Moreover, faith in management systems and procedures as a panacea for enhancing quality is part of a broader trend that cuts across public services (Dahler-Larsen 2008; Power 2010). What is also essential is that inspections appear to be the most important evaluation that exists for the residential homes and passing inspections is not only a prerequisite for being allowed to continue to operate in the sector - living up to standards also means that the homes adhere to officially sanctioned practices that signal 'good quality' and which have an impact on the legitimacy of the residential home (cf. Meyer and Rowan 1977).

Swedish residential care is a welfare service that has been subject to concerns regarding the quality of care and where available research points at poor long-term results. The main policy response in recent years has been to reinforce the inspection system, rather than, for example, raising the requirements on the educational level of the staff or evaluating the treatment effects of care. Inspection is an instrument that may indeed increase the possibility to detect - and intervene against - care providers whose care is poor and which, in the worst-case scenario, may harm children. Moreover, inspections may increase the possibility of providing information on the regulations and may have a behavioural impact in that the care providers become more cautious. However, complying with the regulatory standards should not be confused with care consequently leading to better results for the children overall. The consensus on the standards between residential staff and the Inspectorate that - according to this study - often seems to be at hand, points at residential care being a field that is receptive to external ideas. Although inspections may indeed support areas of care that evidently help to rehabilitate children, such as strong school support, viable relationships between children and adults, collaboration with the birth family and powerful leaving-care programmes (Whittaker et al. 2014), this study shows that inspections may also make residential staff adhere to standards that - whilst being important - may not be or are only partially relevant for the effects of care and the wellbeing of the children.

\section{Note}

1. 'Lex Sarah' is a regulation, which prescribes that an employee who performs social services is bound to report irregularities or the risk of irregularities to the provider of the services. The provider of the services ought to investigate and remedy the irregularities and, if there are serious irregularities, report this to the IVO.

\section{Funding}

This work was supported by the Swedish Research Council (Vetenskapsrådet).

\section{References}

Barth, Richard P., Karen M. Kolivoski, Michael M. Lindsey, Bethany R. Lee, and Kathryn S. Collins. 2014. “Translating the Common Elements Approach: Social Work's Experiences in Education, Practice, and Research." Journal of Clinical Child \& Adolescent Psychology 43 (2): 301-311.

Bemelmans-Videc, Marie-Louise, Ray C. Rist, and Evert Vedung. 2010. Carrots, Sermons and Sticks. Policy Instruments and their Evaluation. New Brunswick, NJ: Transaction Publishers.

Bergmark, Anders, Åke Bergmark, and Tommy Lundström. 2011. Evidensbaserat socialt arbete. Teori, kritik, praktik [Evidence Based Social Work. Theory, Critique, Practice]. Stockholm: Natur \& Kultur.

Boyne, George, Patricia Day, and Richard Walker. 2002. “The Evaluation of Public Service Inspection: A Theoretical Framework." Urban Studies 39 (7): 1197-1212.

Dahler-Larsen, Peter. 2008. Kvalitedens beskaffenhed [The Nature of Quality]. Odense: Syddansk Universitetsforlag.

Evetts, Julia. 2011. "A New Professionalism? Challenges and Opportunities." Current Sociology 59 (4): 406-422.

Hämberg, Eva. 2014. "Supervision as Control System: The Design of Supervision as a Regulatory Instrument in the Social Services Sector in Sweden." Scandinavian Journal of Public Administration 17 (3): 45-64. 
Hood, Christopher, Oliver James, George Jones, Colin Scott, and Tony Travers. 1999. Regulation inside Government. Oxford: Oxford University Press.

IVO (The Inspectorate of Health Care and Social Welfare). 2013. En trygg och säker vård - har personalen lämplig utbildning? [A Safe and Secure Care - Do Staff Have Appropriate Training?]. Stockholm: IVO.

Johansson, Vicki, and Lena Lindgren. 2013. Uppdrag offentlig granskning [Mission Public Audit]. Lund: Studentlitteratur. Le Grand, Julian, and Will Bartlett. 1993. “The Theory of Quasi Markets.” In Quasi Markets and Social Policy, edited by J. Grand and W. Bartlett, 13-34. London: Palgrave Macmillan.

Meagher, Gabrielle, Tommy Lundström, Marie Sallnäs, and Stefan Wiklund. 2015. "Big Business in a Thin Market: Explaining the Privatization of Residential Care for Children and Youth in Sweden." Social Policy \& Administration. doi: http://dx.doi.org/10.1111/spol.12172.

Meyer, John W., and Brian Rowan. 1977. "Institutionalized Organizations - Formal Structure as Myth and Ceremony." American Journal of Sociology 83 (2): 340-363.

Munro, Eileen. 2004. “The Impact of Audit on Social Work Practice.” British Journal of Social Work 34: $1075-1095$.

NAO (National Audit Office). 2002. Tillsyn av behandlingshem för barn och unga [Inspection of Treatment Institutions for Children]. Stockholm: Riksrevisionsverket.

NBHW (The National Board of Health and Welfare). 2010. Nationella bedömningskriterier för tillsyn av kvalitet och säkerhet vid HVB för barn och unga samt familj [National Assessment Criteria for Supervision of Quality and Safety in Institutions for Children and Youth and Families]. Stockholm: Socialstyrelsen.

NBHW. 2014. Barn och unga - insatser år 2013 [Children and Youth - Interventions 2013]. Stockholm: Socialstyrelsen.

Nordstoga, Sigrid, and Anne Marie Stokken. 2011. "Professional Work in the Squeeze: Experiences from a New Control Regime in Residential Care for Children and Youth in Norway." Journal of Comparative Social Work 2: 1-18.

Pålsson, David. 2015. "Conditioned agency? The role of children in the audit of Swedish residential care." Child \& Family Social Work, doi: http://dx.doi.org/10.1111/cfs.12234

Power, Michael. 1999. The Audit Society. Oxford: Oxford University Press.

Power, Michael. 2003. "Evaluating the Audit Explosion." Law \& Policy 25 (3): 185-202.

Power, Michael. 2010. Organized Uncertainty. Designing a World of Risk Management. New York: Oxford University Press.

Sallnäs, Marie. 2012. "Institutionsvård för barn och unga." [Institutional Care for Children and Youth.] In När samhället träder in - barn, föräldrar och social barnavård [When Society Intervenes - Children, Parents and Child Welfare], edited by Ingrid Höjer, Marie Sallnäs, and Yvonne Sjöblom, 185-207. Lund: Studentlitteratur.

Sallnäs, Marie, and Bo Vinnerljung. 2008. "Into Adulthood: A Follow-up Study of 718 Young People Who Were Placed in Out-of-home Care during Their Teens." Child and Family Social Work 13: 144-155.

Sallnäs, Marie, and Stefan Wiklund. 2015a. "Familjehemsvård i granskningssamhället - hur följer kommunerna upp sina placeringar?" [Foster care in the audit society - how does the municipalities follow up their placements?] Socionomens forsknings supplement, 38: 26-43.

Sallnäs, Marie, and Stefan Wiklund. 2015b. “Konkurrensutsättning av individ-och familjeomsorgen - om marknadssärdrag och statlig tillsyn." [Competitive tendering in the personal social services - on market characteristics and state inspection] In Människobehandlande organisation [Human Service Organizations], edited by Peter Dellgran, Staffan Höjer, and Staffan Johansson, 314-330. Stockholm: Natur \& Kultur.

Sallnäs, Marie, Bo Vinnerljung, and Pia Kyhle Westermark. 2004. "Breakdown of Teenage Placements in Swedish Foster and Residential Care.” Child \& Family Social Work 9 (2): 141-152.

Sallnäs, Marie, Stefan Wiklund, and Hélène Lagerlöf. 2012. "Welfare Resources among Children in Care." European Journal of Social Work 15 (4): 467-483.

Shore, Cris, and Susan Wright. 2000. "Coercive Accountability. the Rise of Audit Culture in Higher Education." In Audit Cultures. Anthropological Studies in Accountability, Ethics and the Academy, edited by Marilyn Strathern, 57-89. London: Routledge.

Silverman, David. 2013. Doing Qualitative Research. London: Sage.

SOU 2007:82. Samordnad och tydlig tillsyn av socialtjänsten [Coordinated and Clear Inspection of Social Services]. Slutbetänkande. Stockholm: Fritzes.

SOU 2009:99. Vanvård I Social Barnavård under 1900-Talet: Delbetänkande [Abuse and Neglect in Child Welfare during the 20th Century: Interim Report]. Stockholm: Fritze.

Svensson, Lennart G. 2010. "Professions, Organizations, Collegiality and Accountability." In Sociology of Professions. Continental and Anglo-Saxon Traditions, edited by L. G. Svensson and J. Evetts, 145-166. Göteborg: Daidalos.

Tilbury, Claire. 2007. “The Regulation of Out-of-home Care.” British Journal of Social Work 37: $209-224$.

Watson, David. 2003. "Defining Quality Care for Looked after Children: Frontline Workers' Perspectives on Standards and All That?" Child and Family Social Work 8: 67-77.

Whittaker, James K., Jorge Fernandez del Valle, Lisa Holmes, and Robbie Gilligan. 2014. Therapeutic Residential Care for Children and Youth: Developing Evidence-based International Practice. London: Jessica Kingsley Publisher.

de Wolf, Inge F., and Frans J. G. Janssens. 2007. "Effects and Side Effects of Inspections and Accountability in Education: An Overview of Empirical Studies." Oxford Review of Education 33 (3): 379-396. 